\author{
SEBASTIAN SOBKOWIAK \\ Uniwersytet im. Adama Mickiewicza w Poznaniu \\ Wydział Teologiczny
}

\title{
Relacje między filozofią a współczesną nauką na przykładzie pism Wernera Heisenberga
}

Współcześnie za miarę postępu dokonanego przez ludzkość przyjęto dość jednomyślnie liczbę przełomowych odkryć naukowych i rozwiązanych problemów medycznych, czasem także skuteczność w rozwiązywaniu trudności natury społecznej. Agresywny pragmatyzm, utylitaryzm, pogardzanie ludźmi nieużytecznymi i racjonalno-umysłowa pycha zadomowiły się w zachodnioeuropejskiej mentalności za kurtyną z napisem: Co ja, my, ludzkość, będziemy $\mathrm{z}$ tego mieli? Zapominając o paradygmacie personalistycznym, zapomniano także o konsekwencjach wynikających z jego odrzucenia. Fizyka stała się dla współczesnych nieuświadamianym arche, zasadą, bez której życie nie miałoby sensu. Dobrze odgrywa rolę absolutu, gdyż jej prawa podtrzymują świat $\mathrm{w}$ istnieniu, porządkują go i działają w sposób wymykający się prostemu oglądowi. Człowiek próbuje zaspokoić głód sensu przez uniezależnienie się od wszystkiego, co go przekracza, odrzucając także krępującą moralność, wierząc jedynie w praktyczny wymiar ludzkiego życia i w to, co w nauce uda się zmierzyć ${ }^{1}$. W czasach królowania pragmatyzmu pytanie o związek fizyki i filozofii może wydawać się niezrozumiałe. Przeświadczenie o pewności wiedzy zdobytej za pomocą metody naukowej kontrastuje z pogardzanym nieraz filozofowaniem, choć jest ono przecież także nauką. Dziś jednak zawęża się często rozumienie pojęcia nauki do nauk empirycznych.

Są one w powszechnym mniemaniu rozdzielone, podobnie jak nauka i religia, rozum i wiara, filozofia i życie codzienne. Wszystkie te antagonizmy, choć pozorne, stanowią dziś niemalże kantowską formę postrzegania świata.

${ }^{1}$ Por. K. Stachewicz, Kilka uwag o racjonalności. Wprowadzenie, „Filozofia Chrześcijańska” 6 (2009), s. 10. 
Ich zestawienie $\mathrm{w}$ przeciwieństwa bierze się paradoksalnie $\mathrm{z}$ tego, że wyrastają one z jednego źródła, którego odkrycie może stanowić znaczne ubogacenie dla każdego filozofa, nawet tego biernego, którym jest każdy z ludzi.

Szczególnie ciekawie prezentuje się związek nauki i filozofii, gdy spojrzymy na proces, który dokonał się na przełomie XIX i XX wieku. Ten czas to okres największych odkryć w fizyce w całych jej dziejach.

Przełomowe teorie: względności i kwantowa, stanowią przewrót w rozumieniu procesów rządzących światem. Można je porównać do rewolucji kopernikańskiej z XVI wieku. Jednym z takich rewolucjonistów, żyjących w czasach wspomnianej przemiany, był także niemiecki uczony, Werner Heisenberg, z którego dzieł skorzystano, aby omówić wspomniany związek.

\section{Okoliczności powstania dzieł Heisenberga}

Od czasów Newtona do początku XX wieku fizyka rozwijała się w szybkim tempie. Dotychczas zdawało się, że ustalone i przyjęte prawa mechaniki Newtona są definitywne, zdolne oprzeć się wszelkiej krytyce, co potwierdzały kolejne eksperymenty fizyków różnych dziedzin. Na gruncie filozofii mogliśmy zaobserwować zmianę w postrzeganiu niektórych terminów, takich jak: przestrzeń, czas, przyczynowość i poznanie, gdy na areopag filozoficznych poglądów wystąpił Kant. Nie zmienił on jednak powszechnego mniemania o świecie, które nadal było bliższe Newtonowi, sformułował jedynie odmienne filozoficzne stanowisko. Także fizyka, której podstawą był mechanicyzm, w niewielkim stopniu uległa proponowanym przez królewieckiego filozofia zmianom². Jednakże, „około 1900 roku przed systemem tym [Newtonowskim - przyp. S.S.] wyrosła podwójna trudność"3. Prawdziwym przełomem stał się wiek XX, ze względu na wielość wybitnych postaci świata fizyki, które zaznaczyły swoje miejsce między innymi przez naukowe odkrycia i nowe teorie. W wielu przypadkach musiały być długo uzasadnianie przez ich twórców, aż zdołały przezwyciężyć opór paradygmatu Newtonowskiego mechanicyzmu.

Jednym z takich twórców jest Werner Heisenberg (1901-1976), ,jeden z najwybitniejszych fizyków XX wieku i w historii fizyki w ogóle"4. Był synem filologa klasycznego, otrzymał więc gruntowne filozoficzne wykształcenie.

2 Por. W. Tatarkiewicz, Historia filozofii, t. 3, Warszawa 2005, s. 272.

${ }^{3}$ C.F. von Weizsäcker, Wernerowi Heisenbergowi in memoriam, w: W. Heisenberg, Częśś i catość, tłum. K. Napiórkowski, Warszawa 1987, s. 5.

${ }^{4}$ A.K. Wróblewski, Stowo wstępne, w: W. Heisenberg, Ponad granicami, thum. K. Wolicki, Warszawa 1979, s. 5. 
Kiedy zaczął interesować się fizyką, teoria kwantowa Plancka była już w zasadzie kompletnie sformułowana, co umożliwiło młodemu Heisenbergowi zapoznanie się z jej pełną treścią ${ }^{5}$. Miał wiele wątpliwości co do jej interpretacji oraz do sformułowanego przez Bohra modelu atomu. Widział potrzebę stworzenia nowej matematyki, zaproponował więc rachunek macierzowy, który bez pojęcia orbit atomowych potrafił wyjaśnić strukturę widma atomowego $\mathrm{i}$ był zgodny z teorią Bohra ${ }^{6}$. Pojęcie orbit atomowych było dla niemieckiego fizyka dużym problemem, ponieważ nie był w stanie wyobrazić sobie, jak atom, w którym elektrony poruszają się po orbitach, może być strukturą stabilną. Postulował więc, że orbita może być określona tylko wtedy, jeżeli określimy dokładnie położenie i pęd elektronu w tej samej chwili. Jednak niemożliwe jest, aby zbadać obie te wielkości za pomocą laboratoryjnego pomiaru, ponieważ każdy akt badawczy niszczy stabilność atomu, tworząc jego inny niż przed pomiarem stan wzbudzony?

Jeżeli chcemy zbadać elektron, informację o nim można uzyskać, na przykład kierując na niego wiązkę światła. Cząsteczki światła - fotony - oddziałują jednak w skali mikroskopowej z elektronami, powodując zmianę ich stanu. To wzajemne oddziaływanie narusza w znaczny sposób położenie i energię elektronu. Możemy więc poznać położenie tej cząstki tylko w momencie obserwacji, wcześniej i później położenia nie można określićs ${ }^{8}$ Tak Heisenberg sformułował swoją słynną relację nieoznaczoności: „Iloczyn nieokreśloności dla położenia i ilości ruchu (przez ilość ruchu rozumie się iloczyn masy i prędkości) nie może być mniejszy niż stała działania Plancka"9. Dodatkowo argumentował, że jeżeli zjawisko obserwowane podlega mechanice kwantowej, to takim samym prawom podlega też akt obserwacji, stąd biorą się problemy $\mathrm{z}$ dokonaniem pomiaru niezmieniającego stanu układu. Ta niedokładność pomiaru ma jednak całkowicie nowy charakter. Nie wynika ona, jak wiele poprzednich problemów fizyki, z niedoskonałości przyrządów pomiarowych lub błędów badacza, lecz należy ona do istoty zjawisk kwantowych i nie może zostać nigdy usunięta ${ }^{10}$.

Nie oznacza to, że Heisenberg zaprzeczał istnieniu zasad przyczynowych w zjawiskach, lecz tylko, że niemożliwe jest ich precyzyjne określenie za pomocą dostępnych środków ${ }^{11}$. Określił w ten sposób pewne granice

${ }^{5}$ Por. C.F. von Weizsäcker, Wernerowi..., w: W. Heisenberg, Część..., s. 6.

${ }^{6}$ Por. P.A.M. Dirac, Matematyczne podstawy teorii kwantów, tłum. M. Heller, „Zagadnienia Filozoficzne w Nauce" XII/1997, s. 108.

${ }^{7}$ Por. C.F. von Weizsäcker, Wernerowi..., w: W. Heisenberg, Część ..., s. 7.

${ }^{8}$ Por. A. van Melsen, Filozofia przyrody, thum. S. Zalewski, Warszawa 1963, s. 333.

9 W. Heisenberg, Część i całość, tłum. K. Napiórkowski, Warszawa 1987, s. 107-108.

${ }^{10}$ Por. K. Kłósak, Metafizyczna i fizyczna zasada przyczynowości wobec relacyj niedokładności W. Heisenberga, ,Roczniki Filozoficzne KUL” I/1948, s. 202.

${ }^{11}$ Por. W. Tatarkiewicz, Historia ..., t. 3, s. 277. 
współczesnej fizyki. Poza fizyczną teorią nieoznaczoności, Heisenberg zajmował się także filozoficznymi implikacjami fizyki współczesnej, zmianą znaczenia pojęć takich jak: materia, czas, przestrzeń i przyczynowość.

\section{Materia}

Źródeł pojęcia materii należy szukać w starożytności. Jednym z konfliktów w stanowiskach filozoficznych był platońsko-demokrytejski spór między idealizmem a materializmem. Zacznijmy od Platona. Dokonał on z punktu widzenia historii myśli szczególnego odkrycia. Zredukował materię do liczb. W dziele Timajos jako składniki materii przedstawił cztery żywioły, składające się z trójwymiarowych brył. Te składały się z trójkątów, a te z odcinków. Odcinek określają dwa punkty - liczby. „I w ten sposób wszystko redukuje się do liczby" "2. Fundamentalną zasadą świata były więc byty idealne - matematyczne. Demokryt i Leukippos byli atomistami materialistami, głoszącymi realne istnienie najmniejszych składników materii (atomów). Ich relacje i zmiana położenia są przyczyną wszelkiej różnorodności i zmienności w przyrodzie ${ }^{13}$.

Pewnym podobieństwem do koncepcji atomistycznej była zbudowana na newtonowskiej kanwie dziewiętnastowieczna nauka o absolutnej przestrzeni, w której poruszają się atomy zgodnie z deterministycznymi prawami klasycznej mechaniki. Pierwsze intuicje końca XIX wieku mogły wydać się filozofom nieoczekiwanym powrotem do demokrytejskich atomów, jednak im obszerniejsza była wiedza fizyczna, tym bardziej opozycyjna stawała się wobec antycznego atomizmu ${ }^{14}$.

W zależności od koncepcji atomom przypisywano następujące własności: niezmienność, niezniszczalność, realność w czasie i przestrzeni, posiadanie niezmiennych cech, rozróżnialność, indywidualność. O ile cechy niezmienności i niezniszczalności obaliła całkowicie teoria względności, te i pozostałe zweryfikowała także mechanika kwantowa ${ }^{15}$.

Albert Einstein w teorii względności zachwiał odwiecznym pojęciem materii, przedstawiając prawo równoważności masy i energii w postaci wzoru

${ }^{12}$ C.F. von Weizsäcker, Filozofia grecka i fizyka wspótczesna, „Zagadnienia Filozoficzne w Nauce" II / 1979/80 s. 15.

${ }_{13}$ Por. A. Łukasik, Filozofia nauki Wernera Heisenberga, w: Filozofia-nauka - religia. Ksiega jubileuszowa dedykowana Profesorowi Kazimierzowi Jodkowskiemu z okazji 40-lecia pracy naukowej, red. P. Bylica, K.J. Kilian, R. Piotrowski i D. Sagan, Zielona Góra 2015, s. 347.

${ }_{14}$ Por. tamże.

15 Por. A. Łukasik, Atomizm dawniej i dziś. O niewspótmierności ontologicznej klasycznego i kwantowomechanicznego pojęcia elementarnych sktadników materii, „Studia Philosophiae Christianae" 45 (2009) 1, s. 136. 
fizycznego: $\mathrm{E}=\mathrm{mc}^{2}$. Zostało ono sformułowane około roku 1906 dzięki analizie zachowania elektronu ${ }^{16}$. Ponieważ podstawowym postulatem szczególnej teorii jest graniczna wartość prędkości światła, oznacza to, że trudniej jest przyspieszyć ciało już poruszające się niż pozostające w spoczynku. Każdej wartości energii ciała jest właściwa bezwładność, a więc masa. Ta relacja jest jednak szczególna, ponieważ przyrost masy bezwładnej wraz z prędkością dla ciał o tak małych masach jak elektron jest stosunkowo niewielki, dlatego nie został wcześniej zauważony. Widzimy więc, że zmiana masy ciała nie jest związana z przyrostem jego ilości. Jest to twierdzenie radykalnie sprzeczne z dotychczasowymi synonimicznymi pojęciami masy i ilości substancji ${ }^{17}$. Jak zauważa Heisenberg: „Zasada równoważności masy i energii, niezależnie od swego znaczenia fizycznego, zrodziła problemy związane z bardzo starymi zagadnieniami filozoficznymi" ${ }^{18}$. Naruszono także postulat niezniszczalności i trwałości materii. Dowiedziono bowiem, że w procesie poruszania się cząstek elementarnych z prędkością bliską prędkości światła mogą powstawać nowe cząstki z ich energii kinetycznej lub ginąć, zamieniając się w promieniowanie, gdy prędkość się zmniejsza. Potwierdzono eksperymentalnie, stosując dawną terminologię, że z niczego (energii nigdy nie przypisywano wartości materialnej) może powstać materia. Taki proces może także przebiegać w stronę odwrotną, gdy niektóre cząstki w wyniku na przykład zderzeń $\mathrm{z}$ innymi anihilują, emitując jedynie promieniowanie ${ }^{19}$.

Dodatkowo w szczególnej teorii mamy do czynienia także z innym zjawiskiem, nazywanym kontrakcją Lorentza. Heisenberg podaje to jako hipotezę: „że poruszające się ciała ulegają kontrakcji, skróceniu w kierunku ruchu, przy czym skrócenie to zależy od prędkości tych ciał, i że w różnych układach odniesienia mamy do czynienia z różnym czasem pozornym"20. Przy prędkościach relatywistycznych (bliskich prędkości światła), mierząc dwa identyczne ciała: pozostające w spoczynku oraz szybko się poruszające, uzyskamy w momencie pomiaru różną długość. Ciało poruszające się skraca się w kierunku ruchu. Co prawda rozmiar w przestrzeni nie należy do istoty bytu, lecz do jego przypadłości, napotykamy tutaj pewną trudność. Mierzalne rozmiary przedmiotu mogą się zmienić tylko przez wybór innego układu odniesienia ${ }^{21}$.

Nie można więc utożsamiać pojęć starożytnych substancja lub materia $\mathrm{z}$ masą rozumianą na gruncie fizyki współczesnej. Postulowanym przez

16 Por. W. Heisenberg, Ponad granicami, thum. K. Wolicki, Warszawa 1979, s. 19.

17 Por. tenże, Fizyka a filozofia, thum. S. Amsterdamski, Warszawa 1962, s. 112.

18 Tamże, s. 113.

${ }_{19}$ Por. tamże, s. 113.

${ }^{20}$ W. Heisenberg, Fizyka ..., s. 107.

${ }^{21}$ Por. R. Katz, Wstęp do szczególnej teorii względności, thum. A. Blinowska, Warszawa 1967, s. $39-40$. 
Heisenberga jedynym dozwolonym twierdzeniem jest zdanie: „[...] masa i energia są dwiema różnymi postaciami tej samej substancji”22, tym sposobem można zgodzić się, że tak pojmowana substancja jest niezniszczalna, przejawia się bowiem raz jako masa, raz jako energia.

Niezmienność na gruncie mechaniki kwantowej także nie ma zastosowania, ponieważ poszczególne atomy w procesie rozpadu lub syntezy promieniotwórczej mogą zmieniać się w inne, o innych właściwościach. Nie tylko jednak pierwiastki promieniotwórcze mogą się przekształcać. Także same cząstki elementarne rozpadają się na inne. Niektóre są trwałe i tylko w wyniku działania siły zewnętrznej ulegają przemianom, są jednak też inne, które samorzutnie (dzięki krótkiemu czasowi życia) się przemieniają. Rozpad cząstek nie jest jednak tak oczywisty, że można do niego zastosować klasyczny język. Jeżeli cząstka rozpada się na kilka składników, to nie znaczy, że przed rozpadem istniały one w niej realnie ${ }^{23}$. Jak twierdzi Heisenberg, ,materia jest więc całkowicie przeobrażalna" ${ }^{24}$, co jest sprzeczne z antycznymi założeniami atomistów.

Ciekawie przedstawia się zagadnienie posiadania przez cząstki elementarne określonych cech. Cechy w mechanice kwantowej są dwojakiego rodzaju. Jedne, zgodne z klasycznym rozumieniem, przysługują niezależnie od pomiaru. Należą do nich np. ładunek lub masa spoczynkowa. Pomiar określa ich wielkość (stan), który był przed pomiarem, w jego czasie i po nim. Gdy dokonamy kolejnego pomiaru (przy zachowaniu tego samego stanu), wynik będzie ten sam. Jednak w przypadku pędu, prędkości i położenia istnieje problem związany z ich pomiarem. Za każdym razem, gdy dokonujemy pomiaru, wynik będzie inny, ponieważ stan tych obiektów nie jest określony, lecz jest reprezentowany przez pewną przestrzeń stanów - możliwości ${ }^{25}$.

Także zagadnienie rozróżnialności poszczególnych cząstek przedstawia się przeciwnie niż w klasycznym paradygmacie. Dowolne cząstki klasyczne, choćby były identyczne, to znaczy takie same pod względem cech, mogą zostać rozróżnione na podstawie położenia lub trajektorii ruchu. Współcześnie, gdy położenie i pęd są jedynie możliwościami zależnymi od aktu pomiaru, nie jest możliwe rozróżnienie dwóch identycznych cząstek. Można to porównać do rzutu dwiema monetami. Jeżeli są one identyczne, tj. nierozróżnialne, jednokrotny rzut przedstawi jedynie trzy stany: (a) na obu wypadnie orzeł, (b) na obu reszka lub (c) po jednym orle i reszce. Jeżeli monety byłyby

${ }^{22}$ W. Heisenberg, Fizyka ..., s. 113.

${ }^{23}$ „Na przykład neutron, gdy wchodzi w skład jąder atomowych, zachowuje się jak cząstka trwała, ale neutron swobodny rozpada się na proton, elektron i antyneutrino elektronowe. Nie znaczy to jednak, że neutron zbudowany jest z protonu, elektronu i antyneutrina elektronowego" - A. Łukasik, Atomizm ..., s. 139.

${ }^{24}$ W. Heisenberg, Fizyka ..., s. 161.

${ }^{25}$ W. Heisenberg, Ponad ..., s. 207. 
rozróżnialne, stany byłyby cztery, ponieważ istotne byłoby, na której monecie wypadł orzeł, a na której reszka. Stan (c) rozpada się na 2 stany (c') orzeł i reszka oraz (c") reszka i orzeł. Z punktu widzenia fizyka cząstki w rozumieniu klasycznym mogą zostać rozróżnione, natomiast w kwantowym - nie ${ }^{26}$.

Separowalność cząstek oznacza ich autonomiczne istnienie w przestrzeni i brak oddziaływań, jeżeli są od siebie znacznie oddalone. To jedna z najpóźniej obalonych właściwości cząstek. Nie sposób bowiem z całkowitą pewnością określić stanu jednej z dwóch oddziałujących cząstek, gdy zmierzymy stan drugiej z nich, ponieważ akt pomiaru oddziałuje nie tylko na cząstkę jemu poddawaną, ale także na cząstkę, która jest $\mathrm{z}$ nią $\mathrm{w}$ relacji ${ }^{27}$.

Powracając do przedstawionego na początku przeciwstawienia Platona i Demokryta, widzimy, że pomimo pozornego zbliżania się nauki XIX wieku do dawnego atomizmu, $\mathrm{w}$ miarę postępu atomizm w demokrytejskim brzmieniu utracił całkowicie swój autorytet. Zanegowano większość praw rządzących materią, zarówno fizycznych, jak i filozoficznych. To, co wiemy dziś o materii, bardziej odpowiada pomysłowi Platona, w którym wszelkie prawa materii redukują się do liczb - wzorów matematycznych, a nie do konkretnych materialnych elementów. Sam Heisenberg formułuje taki wniosek: „Fizyka współczesna zdecydowanie odrzuca tę tezę materializmu Demokryta i opowiada się za stanowiskiem Platona i pitagorejczyków"28.

Heisenberg w porównywaniu koncepcji pitagorejczyków ze współczesną idzie jeszcze dalej, twierdząc, że same atomy nie są korpuskułami (cząstkami), lecz bardziej formami matematycznymi. Co prawda nie są to formy tak banalne, jakie zaproponował Pitagoras - figury geometryczne w płaszczyźnie euklidesowej, lecz formy zaawansowanej dynamicznej matematyki, która dopiero się tworzy. Jest to związane z falowymi własnościami materii, które w zasadzie są możliwe do wyrażenia równaniem funkcji falowej. Sama cząstka przestaje więc być bryłą w przestrzeni, gdyż lepiej można określić ją za pomocą funkcji falowej. Nie jest ona wprawdzie zdolna powiedzieć wszystkiego o danej cząstce, lecz daje pewien jej obraz, który można wykorzystać w dalszych obliczeniach i doświadczeniach. Wiele współczesnych dociekań fizycznych opiera się właśnie na badaniu własności równań falowych nieznanych składników mikroświata ${ }^{29}$.

Na koniec rozważań o subatomowej strukturze świata należy poczynić ważną uwagę, którą formułuje również sam Heisenberg. „Na pierwszy rzut oka mogłoby się wydawać, że filozofowie greccy mieli jakąś genialną intuicję, skoro doszli do tych samych albo bardzo podobnych wniosków, do jakich

\footnotetext{
26 Por. A. Łukasik, Atomizm..., s. 153.

27 Por. tamże, s. 159.

28 W. Heisenberg, Fizyka..., s. 51.

29 Tamże.
} 
doszła nauka nowożytna po wielu stuleciach wytężonej pracy wielu badaczy posługujących się eksperymentem i matematyką. Wniosek taki byłby całkowicie niesłuszny"30. Wielkim zawodem byłoby stwierdzenie, że po włożeniu tak wielkiego wysiłku znaleźliśmy się znów w punkcie wyjścia. Nauka współczesna korzysta jednak z zupełnie innej metody, opierając swoje prace na wnioskowaniu empirycznym. Nie znaczy to, że wzgardzono metodą filozoficzną. Za jej pomocą nie można jednak tworzyć fizycznych eksperymentów. Natomiast $\mathrm{z}$ twierdzeń nauki współczesnej można wywnioskować wiele jeszcze bardziej fundamentalnych właściwości, które wszystkie tworzą spójny system. „Mimo wszystko jest faktem, że niektóre twierdzenia antycznej filozofii przypominają koncepcje nauki współczesnej. Świadczy to o tym, jak daleko można zajść nawet bez dokonywania eksperymentów, jeśli dane potocznego doświadczenia niestrudzenie usiłuje się uporządkować logicznie i ująć z punktu widzenia pewnych ogólnych zasad"31.

\section{Czas}

Drugim szczególnym terminem, obecnym zarówno w filozofii, jak i w fizyce, jest czas. Heisenberg pyta: „Co było, zanim rozpoczął się upływ czasu? Co nastąpi, gdy się on skończy? A może czas w ogóle nie ma początku ani końca?"32.

Teoria względności Einsteina zrewolucjonizowała podejście do pojęcia czasu. Do chwili jej powstania, niezależnie czy definiowano czas jako subiektywny, czy obiektywny, mierzono go w ten sam sposób. Przede wszystkim jasne było, że jeżeli zsynchronizujemy dwa zegary, to niezależnie jakie dwa zdarzenia będą równoczesne przy pomiarze dokonanym przy jednym z nich, będą także równoczesne przy pomiarze dokonanym przy użyciu drugiego zegara. Einstein jednak precyzuje, że według postulatów jego teorii zdarzenia będą równoczesne tylko, gdy będą jednakowo odległe od obu obserwatorów. W innych przypadkach zdarzenie pierwsze może być przez pewnego obserwatora dostrzeżone jako wcześniejsze od drugiego, przez innego zaś jako późniejsze od drugiego. Wszystko zależne jest od położenia i prędkości obserwatorów ${ }^{33}$. Oczywiście nie można tutaj zanegować istnienia związków przyczynowych, ponieważ jeżeli jedno zdarzenie wywołuje drugie, to znaczy nie można w żaden sposób odwrócić ich kolejności przez wybór innego aktu

\footnotetext{
30 W. Heisenberg, Fizyka..., s. 61.

31 Tamże, s. 62.

32 Tamże, s. 119.

33 Por. R. Katz, Wstęp..., s. 35.
} 
odniesienia ${ }^{34}$. Fałszywe jest klasyczne twierdzenie, że uniwersalny czas płynie jednakowo dla wszystkich ${ }^{35}$. Heisenberg, komentując, pisze: ,jeżeli zaś chodzi o czas, to wydaje się, że istnieje coś w rodzaju jego początku"36.

Najważniejszą fizyczną zmianą, która wpłynęła na takie rozumienie, była zmiana stanowiska opartego na fizyce newtonowskiej, że sygnały mogą się rozchodzić z nieskończoną prędkością. Od czasów Einsteina wiemy, że prędkość ta jest skończona i wynosi c=300 $000 \mathrm{~km} / \mathrm{s}$. Oznacza to, że nie można zsynchronizować w jednej chwili wszystkich zegarów we wszechświecie i arbitralnie orzec, które zdarzenia należą do przeszłości, teraźniejszości i przyszłości. Czas jest u Einsteina względny, i to nie tylko subiektywnie - zależnie od obserwatora, ale względny w zależności od wyboru układu odniesienia. Także podział na przeszłość i przyszłość jest względny. Jak widać, teoria względności bardziej posługuje się pojęciem równoczesności niż czasu, ponieważ znajduje ono odzwierciedlenie w opisywaniu eksperymentów fizycznych. Einstein tak mówił o swojej koncepcji czasu:

Chcąc opisać ruch cząstki, podajemy wartości jej współrzędnych jako funkcji czasu. Musimy jednak pamiętać, że taki opis matematyczny ma sens tylko wtedy, gdy jest w pełni jasne, co rozumiemy tutaj przez czas. Należy zatem pamiętać, że wszystkie nasze sądy dotyczące czasu są sądami o zdarzeniach równoczesnych. Jeżeli na przykład mówić, że pociąg przyjeżdża tutaj o godzinie siódmej, oznacza to mniej więcej: wskazanie przez małą wskazówkę mojego zegarka godziny siódmej i przybycie pociągu to zdarzenia równoczesne ${ }^{37}$.

Równoczesność nie jest metafizycznie obiektywną własnością zdarzeń, a jest określana empirycznie, na drodze obserwacji eksperymentalnej.

Jednym ze zjawisk relatywistycznych jest też dylatacja czasu, wynikająca z zastosowania transformacji Hendrika Lorentza. Wynika z niej, że zegar, który się nie porusza, będzie inaczej mierzył czas niż zegar poruszający się. Przedział czasu w układzie poruszającym się ulega wydłużeniu. Efekt ten można jednak badać wyłącznie z perspektywy drugiego układu odniesienia. Nie można zmierzyć go w przypadku, gdy poruszamy się w tym samym układzie inercjalnym. Co ciekawe jednak, gdy zmienimy układ odniesienia, przenosząc się do układu poruszającego się, będzie nam się wydawać, że to czas w tym pierwszym układzie płynie wolniej. Efekt dylatacji czasu jest więc

${ }^{34}$ Por. M. Heller, M. Lubański, S. Ślaga, Zagadnienia filozoficzne wspótczesnej nauki - wstęp do filozofii przyrody, Warszawa 1992, s. 212.

${ }_{35}$ Por. M. Tempczyk, Czas we wspótczesnej fizyce, „Ethos” nr 3(99) 2012, s. 238.

${ }^{36}$ W. Heisenberg, Fizyka..., s. 122.

${ }^{37}$ A. Einstein, O elektrodynamice ciat w ruchu, w: tenże, 5 prac, które zmienity oblicze fizyki, thum. P. Amsterdamski, Warszawa 1998, s. 123, cyt. za A. Przechowski, „Równoczesność” a „teraźniejszośc” - fizyka i metafizyka czasu, „Roczniki Filozoficzne KUL”, tom LXII, 4/2014, s. 186n. 
względny i symetrycznie zachodzi w obu układach odniesienia. Jest to kolejny argument przeczący absolutnemu pojęciu czasu ${ }^{38}$.

\section{Nieoznaczoność procesów kwantowych}

Zasada przyczynowości w wersji tradycyjnej milcząco zakłada, że świat zewnętrzny jest przez nas poznawalny i uporządkowany na tyle, aby można było go badać i tworzyć ogólne zasady. Jako podstawowe uznaje się dwa prawa: (1) nic nie dzieje się bez przyczyny oraz (2) podobnym przyczynom towarzyszą podobne skutki ${ }^{39}$.

$\mathrm{Na}$ nich opiera się fizyka mechanistyczna, pozwalają one tworzyć eksperymenty i wyciągać z nich pewne wnioski. Co więcej, pozwalają różnym naukowcom, niezależnie od siebie przeprowadzać w laboratoriach opisane na papierze eksperymenty, które przy zachowaniu tych samych warunków dają te same rezultaty. Zasadę tę sformułowali neoscholastycy: „W rzeczywistości materialnej bieg wydarzeń jest tak zdeterminowany, że ta sama przyczyna w tych samych warunkach wywołuje zawsze i z konieczności ten sam skutek"40.

W tradycji przyczynowość często wiązano z czasem, miało to miejsce na przykład w teorii relacyjnej lub kauzalnej. W nich jako miarę czasu przyjmuje się relację między nierównoczesnymi zdarzeniami: to jest wcześniejsze w czasie, które jest w danym zjawisku przyczyną, natomiast skutek jest zawsze późniejszy. Teoria kauzalna postuluje natomiast, że ten stan wszechświata jest wcześniejszy, który zwiera w sobie przyczynę następnego. Według niej, badając poszczególne stany pod względem przyczyn, można by je uporządkować chronologicznie jeden po drugim, podobnie w myśl zasady, że przyczyna poprzedza skutek w czasie ${ }^{41}$.

Dla Kanta przyczynowość stanowiła, podobnie jak czas i przestrzeń, zmysłową formę umysłu, która co prawda nie istnieje obiektywnie jako forma zjawisk, ale absolutnie subiektywnie w umyśle. W zasadzie źródła wszelkiej nauki i badania świata należy szukać w starożytnym odkryciu związku przyczynowego. Cała nauka do wieku XX była więc deterministyczna - związek przyczyn ze skutkami stanowił absolutny warunek badań ${ }^{42}$.

${ }^{38}$ Por. R. Katz, Wstęp ..., s. 37; M. Heller, Filozoficzne..., w: M. Heller, M. Lubański, S. Ślaga, Zagadnienia..., s. 214.

${ }^{39}$ Por. B.J. Gawecki, Zagadnienie przyczynowości w fizyce, Warszawa 1969, s. 17.

${ }^{40}$ K. Kłósak, Metafizyczna ..., s. 198.

${ }^{41}$ Por. T. Pabjan, Czas, hasło internetowej Encyklopedii Filozofii Przyrody KUL, http://www. kul.pl/files/57/encyklopedia/pabjan_czas.pdf [dostęp: 08.08.2018].

${ }^{42}$ Por. W. Tatarkiewicz, Historia ..., t. 3, s. 276. 
Przyczynowa struktura wszechświata umożliwiała także przewidywanie zjawisk, gdyż znając dokładnie stan układu oraz działającą przyczynę, można było określić jego przyszły stan ${ }^{43}$. Powstanie zasady nieoznaczoności wiąże się z bardzo szybkim rozwojem fizyki eksperymentalnej w XX wieku. Naukowcy zaczęli budować coraz dokładniejsze przyrządy pomiarowe i uzyskiwać wyniki liczbowe obarczone mniejszym błędem. Początek stosowania elektroniki, który powoli eliminował człowieka z eksperymentu jako element powodujący największe błędy i najbardziej zmienny przy wielu pomiarach, dał nadzieję na zbadanie i opisanie całego mikroskopowego świata. Fizyka klasyczna umożliwiała wielokrotne powtarzanie tych samych pomiarów, których suma dawała jeszcze dokładniejszy wynik. Pragnieniem było dojście do podstaw budowy wszechświata, do najmniejszych elementów materii i przyczyn mikrozjawisk. Wszystko jednak opierało się na błędnym przeświadczeniu, że świat atomowy jest wielokrotnie zmniejszonym światem, którego doświadczamy, a więc, że rządzą nim te same prawa ${ }^{44}$.

W świecie atomowym panuje zasada nieoznaczoności Wernera Heisenberga. Stosuje się ją do tych dwóch własności, które są ze sobą sprzężone (nie komutują) ${ }^{45}$. Takimi własnościami są: położenie (współrzędne $\left.x, y, z\right)$, pęd $(p)$, czas $(t)$ oraz energia $(W)$. Nierówności wyrażające to prawo mają postać:

$$
\begin{gathered}
\Delta x \cdot \Delta p_{x} \geq h \\
\Delta y \cdot \Delta p_{y} \geq h \\
\Delta z \cdot \Delta p_{z} \geq h \\
\Delta t \cdot \Delta W \geq h^{46}
\end{gathered}
$$

Trzy pierwsze nierówności przedstawiają zależność położenia (trzech składowych) i pędu, ostatnia natomiast czasu od energii. Im dokładniej określimy położenie cząstki, tym mniej dokładnie będziemy znali jej pęd i odwrotnie, a także im dokładniej określimy wartość energii przekazanej w procesie kwantowym, tym mniej dokładnie poznamy czas jego trwania. Samo jeszcze takie stwierdzenie nie jest całkowicie niezrozumiałe, doświadczamy wszak niedokładności pomiarowych w eksperymentach także w dużej skali, tu jednak jest ono istotowo różne. Zakłócenie pomiaru ma charakter kwantowy i jest obecne nie w akcie pomiaru, ale w samym obiekcie obserwowanym. Nie można więc oczekiwać, że w procesie rozwoju nauki zostanie kiedyś zniwelowane ${ }^{47}$.

${ }^{43}$ Por. B. J. Gawecki, Zagadnienie..., s. 19.

${ }^{44}$ Por. M. Heller, Logos ..., s. 223.

${ }^{45}$ Komutacja (przemienność) - możliwość przemiennego badania dwóch własności ciał, w którym badanie jednego nie zmienia wartości drugiego, kolejność wykonywania pomiarów nie jest istotna. Jest to własność świata makroskopowego, lecz nie zawsze jest prawomocna w świecie mikroskopowym. Por. M. Heller, Elementy mechaniki kwantowej dla filozofów, Kraków 2014, s. 67.

${ }^{46} h$-stała Plancka, forma wzoru za: K. Kłósak, Metafizyczna ..., s. 198.

${ }^{47}$ Por. K. Kłósak, Metafizyczna..., s. 202. 
Heisenberg twierdzi, że w fizyce atomowej nie można nigdy pominąć oddziaływania badanego przedmiotu z przyrządem pomiarowym i światem zewnętrznym, a także z samym aktem pomiaru, tak jak można to uczynić w mechanice klasycznej poprzez udoskonalenie urządzeń lub powtarzanie eksperymentów ${ }^{48}$.

W mechanice klasycznej opis doświadczenia jest następujący: bada się położenie spoczynkowe ciała z dowolnie dużą dokładnością, następnie, znając prędkość, z którą się porusza, lub przyłożoną do niego siłę, obliczamy jego końcowe położenie po dowolnym czasie na podstawie praw mechaniki. W ten sposób astronomowie są w stanie przewidywać ruchy planet, ich zaćmienia i oddziaływania. Badanie zjawisk atomowych wywołało jednak poważny kryzys.

Heisenberg przywołuje tutaj pewien eksperyment myślowy. Jeżeli chcemy zbadać obiekty zbyt małe dla naszego wzroku, sięgamy po mikroskop. Jednak nawet najlepszy mikroskop nie mógłby dać nam wglądu do wnętrza atomu, gdyż długość fali światła (granica stosowalności mikroskopu) jest większa niż średnica atomu. Można użyć do tego celu mikroskopu działającego z użyciem fal $\gamma$ (gamma), których długość umożliwia obserwacje atomów. Tu jednak napotykamy problem. Jeżeli dokonujemy pomiaru, przynajmniej jeden kwant promieniowania musi uderzyć $\mathrm{w}$ elektron poruszający się $\mathrm{w}$ atomie. Tym uderzeniem zmienia jednak pęd i prędkość elektronu, nie da się więc przewidzieć w sposób pewny jego dalszego toru. Kolejny pomiar da nam informację o kolejnym przybliżonym położeniu, jednak nie wiemy nic o torze elektronu pomiędzy kolejnymi pomiarami. Na podstawie pomiaru pierwszego możemy podać statystycznie możliwe położenia, w których znajdzie się po określonym czasie elektron, jednak każde z nich jest tak samo pewne, aż do momentu następnego pomiaru ${ }^{49}$.

W modelu nowej mechaniki zachwiana została, dotychczas uważana za pewną, filozofia deterministyczna. Nie może ona mieć zastosowania, gdyż już na samym początku napotykamy ważny problem: ustalenia dokładnego obecnego stanu układu. Nie możemy opisać toru jego lotu w przestrzeni, gdyż nie wiemy dokładnie, w którym miejscu zaczyna się jego tor i w którym się kończy. Nie zostaje natomiast zanegowana relacja przyczyna-skutek, gdyż nadal skutek nie może czasowo wyprzedzać przyczyny. Wiemy przecież, że zawsze skutkiem pomiaru jest zmiana stanu układu ${ }^{50}$. Lepiej jest więc na określenie

${ }^{48}$ Por. M. Heller, Filozoficzne zagadnienia mechaniki kwantowej, w: M. Heller, M. Lubański, S. Ślaga, Zagadnienia ..., s. 271.

${ }_{49}$ Por. W. Heisenberg, Fizyka..., s. 30.

${ }^{50}$ Podobnie jak w teorii względności, choć czas nie może być absolutnym odniesieniem dla zjawisk, gdyż nie biegnie dla wszystkich w ten sam sposób, to jednak ciągle skutek nie może poprzedzać przyczyny. 
negacji determinizmu fizyki współczesnej użyć terminu niezas to sowaln o ść, gdyż w deterministycznym zdaniu nie została zanegowana cała implikacja $^{51}$, lecz udowodniono, że pierwszemu członowi implikacji nie można nigdy przypisać wartości prawdy w sposób pewny. Ostatecznie więc determinizm jako taki nie został zanegowany, jednak na gruncie fizyki współczesnej należy stwierdzić, że jest ona w całości indeterministyczna ${ }^{52}$.

To, że nie jesteśmy w stanie określić dokładnego miejsca położenia cząstki (lub pędu, energii), nie oznacza bynajmniej, że w danym momencie nie ma ona dokładnie określonej tej wielkości. Cząstka istnieje realnie nawet, gdy nie jest obserwowana, i ma wszelkie swoje właściwości, podobnie jak istnieje każdy inny byt, który przestajemy w pewnej chwili obserwowaćs ${ }^{53}$. Niektórzy fizycy jednakże twierdzą, powołując się na dualizm korpuskularno-falowy, że cząstka istnieje realnie w taki sposób, w jaki ją badamy (gdy badamy jako falę - istnieje jako fala, gdy jako cząstkę - istnieje jako cząstka) ${ }^{54}$.

Pozostając na gruncie fizyki, zauważamy, że także podstawowe pojęcia logiki załamują się, gdy wkraczamy w subatomowy świat. W pierwszym przypadku, gdy określamy stany i zachowania układów, należy stwierdzić, że nie sposób każdemu kwantowemu wydarzeniu przypisać wartości prawda lub fałsz. Te wartości bowiem odpowiadają prawdopodobieństwom $1=$ prawda lub 0 = fałsz. Wiemy natomiast, że prawdopodobieństwa mogą rozkładać się dowolnie w zbiorze $\mathrm{P}=<0,1>$. Dobrze ilustruje to eksperyment interferencyjny z dwiema szczelinami wykonany po raz pierwszy przez Thomasa Younga, a zinterpretowany na nowo przez Louisa de Broglie'a. Badano w nim światło oraz cząstki przechodzące przez szczeliny i padające na ekran. To, że pojedyncze elektrony powodują powstanie prążków interferencyjnych, nie oznacza, że każdy z nich przeszedł przez jedną lub drugą szczelinę, takie stwierdzenie nie jest uprawnione w świecie kwantowym. Heisenberg nie obalił klasycznej logiki, lecz pokazał, że w świecie mikro panuje logika wielowartościowa ${ }^{55}$.

Dowiedziono, że „prawa kwantowe muszą być natury statystycznej" ${ }^{56}$. Przykładem ilustrującym tę prawidłowość jest też znany wcześniej rozpad pierwiastków promieniotwórczych. Każdy z nich ma określony czas połowicznego rozpadu, jednak nie możemy dowiedzieć się dokładnie, w którym momencie wyemitowana zostanie cząstka $\alpha$ (alfa). Co więcej, podobnie jak w relacji

${ }^{51}$ Implikacja jest fałszywa tylko wtedy, gdy poprzednik implikacji jest prawdziwy, a następnik fałszywy, tj. gdy z prawdy wynika fałsz.

${ }_{52}$ Por. K. Kłósak, Metafizyczna..., s. 212.

${ }_{53}$ Por. R. Więckowski, Ku ontologii obiektów kwantowych, „Studia Philosophiae Christianae” nr 2, 2003, s. 368.

${ }^{54}$ Por. B.J. Gawecki, Zagadnienie..., s. 52.

${ }_{55}$ Por. M. Heller, M. Lubański, S. Ślaga, Zagadnienia ..., s. 271.

${ }^{56}$ W. Heisenberg, Ponad..., s. 134. 
nieoznaczoności, nie będzie nigdy można odkryć tego momentu, gdyż prawdopodobieństwo jest istotowo związane z procesami kwantowymi. Heisenberg postuluje, że to świat makroskopowy jest przypadkiem granicznym kwantowego - jest to świat tak wielkich prawdopodobieństw (bliskich jedności), że w większości przypadków możemy mówić, że procesy w nim są zdeterminowane ${ }^{57}$.

\section{Teoria unifikacji i język fizyki}

„Wszelkie dotychczasowe rewolucje w fizyce były związane z głębokimi zmianami pojęciowymi”’58. Mamy tutaj na myśli rewolucję Newtonowską, która przyniosła nowe pojęcia siły, pędu oraz fakt mierzalności rzeczywistości. Unifikacja to teoria, która także ma swoje źródła w starożytności, jest jednak cały czas obecna w dyskusjach fizyków.

Wszystkie, bez wyjątku, starożytne doktryny filozoficzne, które zawierały w sobie wskazanie na elementarną zasadę rzeczywistości arche mogą być uznane za pierwsze teorie unifikacji. Nie opierały się one, co prawda, na wiedzy eksperymentalnej, lecz bazowały na refleksjach rozumowych. Nie były też całkowicie unifikujące, ponieważ obejmowały tylko to, czego tamtejszy człowiek mógł doświadczyć: świat wokół siebie. Nie obejmowały całego wszechświata, a prawa, które zawierały, odnosiły się tylko do kilku znanych procesów oraz do relacji między poszczególnymi $\operatorname{arch} i^{59}$.

Dalszy rozwój, choć nie można odmówić mu ważności, był jedynie powiększaniem wiedzy i formułowaniem coraz to nowszych praw rządzących przyrodą. Były to prawa oparte na mechanice, na tamten czas rozumiane jako uniwersalne. Dlaczego nie można nazwać mechaniki teorią ostateczną? „Mechanika nie mogła być teorią ostateczną, bowiem właściwie nie jest teorią zjawisk fizycznych, lecz ogólnym schematem tworzenia teorii fizycznych" Na jej podstawie można tworzyć nowe teorie, ale nie wszystkie są do końca z nią zgodne. Ponadto wiele twierdzeń biologii czy chemii, które rozwijały się w oderwaniu od fizyki, nie wynikało z mechanicyzmu lub nie zgadzało się z nim. Co prawda Newton twierdził, że jego prawa są uniwersalne, ale nie znał rozmiarów i skali wszechświata. Od teorii ostatecznej oczekuje się też, że zdefiniuje najbardziej podstawowe definicje fizyczne, takie jak czas i przestrzeń, zasadę wielości i model wszechświata ${ }^{61}$.

57 Por. tamże.

58 M. Heller, Logos wszechświata, Kraków 2013, s. 227.

59 Por. L. Sokołowski, W poszukiwaniu teorii ostatecznej, w: Przestrzenie księdza Cogito. Księdzu Michałowi Hellerowi w sześćdziesiąta rocznicę urodzin, red. S. Wszołek, Tarnów 1996, s. 89.

60 Tamże, s. 92.

61 Por. M. Heller, Logos..., s. 227. 
W ogóle można powiedzieć, że rozwój nauki dokonał się na drodze pewnego rodzaju unifikacji. Była to unifikacja specyficznego rodzaju - można nazwać ją pierwszego stopnia - redukująca poszczególne zjawiska do praw ogólnych, nosząca nazwę indukcji. Tak powstała nauka, która szukała wyjaśnienia dla wielości, posługując się jednym w danej kategorii stwierdzeniem. Jej konsekwencją było sformułowanie wielu praw, które co prawda nie były od siebie zależne, ale w całości obejmowały prawie wszystkie dziedziny nauk ścisłych. Drugim stopniem unifikacji można nazwać proces rozszerzania jednego prawa na różne dziedziny. Próbowano tego dokonać, rozszerzając mechanikę na inne obszary nauki, ale jak już wspomnieliśmy, zakończyło się to fiaskiem. Osiągnięcia mechaniki kwantowej, która zajmuje się najgłębszą warstwą znanego nam świata, pozwoliły na nowo zainteresować się próbą unifikacji fizyki. Dokona się ona jednak na poziomie metanaukowym, gdyż określi nie tylko same prawa, ale także sposób ich formułowania oraz kwestie języka, którym należy je opisywać ${ }^{62}$.

W wieku XX powstały jednak dwie znaczące teorie: względności i kwantowa. Czy nie są one pełnoprawnymi unifikacjami fizyki? Fizyka zredukowała wszelkie oddziaływania w przyrodzie do następujących: (1) elektromagnetycznego, (2) grawitacyjnego, (3) jądrowego, (4) słabego. Żadna z teorii nie wyjaśnia wszystkich czterech oddziaływań. Naukowcy spierają się co do metody unifikacji: czy wszystkie te oddziaływania zostaną ujednolicone w jednej nowej teorii, czy też z pomocą znanych zostaną wyjaśnione. Dotychczas jednak nie powstała w całości zunifikowana fizyczna teoria wszystkiego ${ }^{63}$.

Heisenberg widzi możliwość unifikacji świata do kilku założeń i prostych równań. Jako przykład, który już dokonał się w historii, pokazuje on osiągnięcie pitagorejczyków. Dokonali oni odkrycia prostego w swej budowie równania dotyczącego trójkąta prostokątnego, które pozwoliło obliczać długości jego boków dla różnych wielkości. Podobnie większość praw fizycznych, choć opisuje procesy skomplikowane, redukuje się do prostych iloczynów i ilorazów matematycznych, zawierających stałe i zmienne elementy. Obliczanie i interpretacja wyników tych równań może jednak nastręczać trudności i wymagać dużej wiedzy. Podobnie może być z teorią unifikacji, która opisze cały wszechświat z pomocą prostych założeń i praw. Trudno jednak spodziewać się, że każdy z ich pomocą będzie mógł bezbłędnie obliczyć sobie stany dowolnych cząstek lub układów kwantowych ${ }^{64}$.

Podejmując refleksję nad filozofią Heisenberga, nie sposób nie wspomnieć o problemie języka, który używany jest w dyskusjach na temat fizyki

\footnotetext{
62 Por. tamże, s. 228.

63 Por. L. Sokołowski, W poszukiwaniu ..., s. 93.

${ }^{64}$ Por. W. Heisenberg, Fizyka..., s. 62.
} 
kwantowej. Wydaje się, że problem języka jest ostatecznym punktem dojścia drogi tej refleksji, ponieważ o ile realne procesy zachodzą od początku istnienia świata nieprzerwanie, rolą nauki jest ich nazwanie i przedstawienie ludzkości w formie zrozumiałej i operacyjnej.

Przez wieki pytanie o język fizyki nie było tak istotne. Tworzono po prostu nowe zrozumiałe pojęcia, które odpowiadały konkretnym wielkościom, procesom, stałym fizycznym. Wszystkie one odnosiły się do świata makroskopowego, a więc do tego, w którym panuje klasyczna mechanika. Mogły być dla laików niezrozumiałe, jednak jedynie z powodu niedostatecznej wiedzy na temat określonych nowych zjawisk. Odnosiły się jednak ciągle do tych samych - możliwych do opisania procesów. Język ten przez wieki był na tyle dokładny i dostępny, że mógł z największą dokładnością opisać najbardziej skomplikowane doświadczenia i procesy. Fakt ten wynikał z tego, że wszelkie odkrycia, których dokonała nauka do XX wieku, były bezpośrednio dostępne zmysłowemu poznaniu ludzkiemu ${ }^{65}$.

Sytuacja zmieniła się, gdy fizycy zaczęli zajmować się obszarami, które dalekie były od percepcyjnych możliwości zmysłów człowieka. Jak wynika z powyższych rozważań, pojęcia podstawowe, takie choćby jak czas i przestrzeń, zyskały nowe znaczenia.

Heisenberg zauważa, że przed kwantową rewolucją proces przebiegał podobnie, gdy do potocznego języka wchodziły co jakiś czas matematyczno-fizyczne neologizmy. Były one jednak z powodzeniem thumaczone za pomocą znanych struktur logicznych i językowych. Dopiero w czasach jemu współczesnych dokonała się w tym względzie ,niesamowita w pewnym sensie odmiana" ${ }^{66}$. Odtąd thumaczenie zjawisk i tworzenie nowych pojęć stało się o wiele trudniejsze. Nie było bowiem możliwe zdefiniowanie ich za pomocą klasycznego języka. Jedyną nazwą dla niektórych zjawisk, które wydają się na pozór jawnie sprzeczne ze zdrowym rozsądkiem, pozostała nazwa „paradoksu" ${ }^{\circ}$.

Jednym z podstawowych problemów mechaniki kwantowej jest metoda prowadzenia eksperymentów. Eksperymentatorzy - ludzie są bytami funkcjonującymi w przestrzeni pośredniej między światem atomowym a kosmicznym, poza ekstremami, w których załamują się pojęcia klasycznej mechaniki. Chcąc owe ekstrema badać, muszą aranżować badania, jednak ich wyniki, aby być dla ludzi dostępne, muszą być wyrażone klasycznym językiem, gdyż innym nie potrafimy się porozumieć. $Z$ drugiej strony nie wystarcza on do opisu procesów kwantowych. Jedynym językiem, którego można użyć, jest

65 Por. W.P. Grygiel, Przekroczyć nieoznaczoność: relacje nauka-religia w myśli Wernera Heisenberga, w: Czy nauka zastąi religię?, red. B. Brożek, J. Mączka, Kraków 2011, s. 90.

66 W. Heisenberg, Ponad..., s. 148.

${ }^{67}$ Por. tamże. 
formalizm matematyki, jednak nie ten prosty, który znamy ze szkolnych lekcji (łatwo przekładalny na klasyczny), lecz formalizm matematyki nieeuklidesowej oparty na wielowartościowej logice ${ }^{68}$.

Pewnym kompromisem jest uznanie komplementarności praw i wyjaśnień. Komplementarność oznacza sposób mówienia o danej rzeczywistości za pomocą różnych, wzajemnie wykluczających się teorii. Każda z nich w swoim układzie odniesienia wystarczająco określa mierzalne własności tej samej rzeczy, jednak logiczne warunki wykluczają jednoczesne ich stosowanie. Gdy dwie własności rzeczy są komplementarne, nie można jednocześnie ich mierzyć. Jeżeli elektron potraktujemy jako cząstkę, nie będziemy mogli zbadać długości jego fali, a jeżeli przyjmiemy, że jest falą, nie będziemy mogli określić jego masy ${ }^{69}$.

Fizycy są więc w stanie opisać w sposób matematyczny formalizm teorii kwantów, jednak istnieje on jako taki sam dla siebie. Aby aranżować eksperymenty, należy dokonać redukcji niejako transcendentnych idei do jednej z komplementarnych teorii i dopiero wtedy przeprowadzić badanie. Wybór metody zależy od cechy, którą chcemy zbadać.

Język teorii kwantów nie może więc przystosować się do tego, którego używamy na co dzień, gdyż nie znajduje w nim dobrych odpowiedników. Także i w drugą stronę przystosowanie nie jest możliwe, gdyż wymagałoby to powszechnego przyjęcia przez ludzi logiki wielowartościowej. Jest jednak ona tak sprzeczna z formami, do których przez wieki przystosował się nasz umysł, że nie można by wygodnie się nią posługiwać ${ }^{70}$. Nie można więc postulować, że w opisie przyrody osiągnie się podobną dokładność i formalność opisu, jak w matematyce ${ }^{71}$.

Wprowadzenie zasady nieoznaczoności do fizyki było jednym z kroków milowych współczesnego przyrodoznawstwa. Jako element nowej kwantowej mechaniki przyczyniła się do zmiany metodologii badań naukowych i interpretacji ich wyników. Wykazała niestosowalność determinizmu i konieczność komplementarnego stosowania różnych metod pomiarowych, zmieniając też podejście do epistemologii ${ }^{72}$. Heisenberg przyczynił się także do zmiany podejścia do języka, którym posługuje się fizyka. Wykazał, że nie można w prosty sposób wyrazić wielu osiągnięć współczesnej fizyki językiem

${ }^{68}$ Por. W. P. Grygiel, Przekroczyć..., s. 92.

${ }^{69}$ Por. W. Heisenberg, Ponad ..., s. 157.

70 Jako uzasadnienie tej tezy podaje Heisenberg przykład: „Z dwóch zdań - powiedzmy «Tutaj stoi stół» i «Tutaj nie stoi stół» - jedno musi być słuszne, a drugie fałszywe, trzeciej możliwości nie ma, tertium non datur. W logice kwantowej [...] mogą występować wartości pośrednie, na przykład $1 / 2$, przy której zdanie jest z takim samym prawdopodobieństwem słuszne, jak fałszywe" - W. Heisenberg, Ponad ..., s. 158.

${ }^{71}$ Por. W.P. Grygiel, Przekroczyć..., s. 92.

72 Por. A. Łukasik, Filozofia ..., s. 353. 
potocznym, gdyż nie ma on $\mathrm{w}$ sobie koniecznych konstrukcji słownych i logicznych. Jego prace są przykładem ukazującym związek, jaki łączy fizykę współczesną z filozofią.

Fizyka i filozofia od wieków rozwijały się we wzajemnej symbiozie, należy jednak zwrócić uwagę na nowe rozumienie tej symbiozy, które zawdzięczamy współczesnym fizykom.

Omawiane teorie fizyczne stanowią przełom, ponieważ zakwestionowały wiele dotychczas uznawanych praw fizycznych. Samo tylko odkrycie różnych postaci praw, które rządzą przyrodą w odmienny sposób, zależny od skali przedmiotów oddziaływań, stanowiło zmianę w myśleniu o jednorodności oddziaływań. Konieczną zmianą była też ewolucja podstawowych pojęć języka, którym posługują się filozofia i fizyka.

Teoria względności zakwestionowała rozumienie natury światła jako poruszającego się z nieskończoną prędkością oddziaływania na rzecz natury korpuskularno-falowej. Materia przestała być określana jako niezmienna i niezniszczalna, zaczęto o niej mówić jako o jednej z postaci energii. Czas określono na nowo jako względny, zależny od obserwatora i układu odniesienia, zniesiono absolutny podział na przeszłość, teraźniejszość i przyszłość.

Także mechanika kwantowa wprowadziła wiele nowych teorii. Atomy podstawowy budulec materii - mogą ulegać przemianom, rozpadowi i syntezie bez zachowania pierwotnych własności. Nie podlegają naocznym badaniom, ponieważ ich stany nie są reprezentowanie przez proste równania, lecz przez funkcję statystyczną, która opisuje je tylko z pewnym prawdopodobieństwem. Teoria unifikacji umożliwia redukcję fizyki do jednego systemu praw i cząstek, który na gruncie filozofii może pretendować do miana podstawowego aksjomatu. Zasada nieoznaczoności Heisenberga uniemożliwia dokładne badanie cząstek, które ze względu na małe rozmiary i podleganie licznym oddziaływaniom nie mogą być precyzyjnie obserwowane.

Mając na uwadze wszystkie te zmiany dokonane w trakcie rozwoju fizyki XX wieku, należy zauważyć następujące prawidłowości, prezentowane w dziełach Heisenberga. Fizyka współczesna dokonała wielkiego postępu, lecz stała się także bardziej indeterministyczna. Wiele procesów opiera się na względnych układach odniesienia, odkryto też takie, w których nie można określić precyzyjnego stanu badanych obiektów ze względu na ich istotę. Naukowcy zaczęli zdawać sobie sprawę z ograniczeń, które sama przyroda na siebie nakłada. W jej obrębie rozwinięto także statystykę, która o obiektach mówi tylko z pewnym prawdopodobieństwem. Fizycy wobec niemożności wytłumaczenia niektórych faktów zwrócili się w stronę 
filozofii, aby redefiniować podstawowe pojęcia, w zgodzie ze swoimi badaniami.

Dzieje omawianego związku na przestrzeni lat można porównać do sinusoidy. U jego początku (Newton) był bardzo ścisły, lecz począł się rozpadać, gdy oświeceniowcy usiłowali ubóstwić metodę naukową kosztem metafizyki. Za przełom uznać można właśnie omawianą fizykę XX wieku, która na gruncie neopozytywizmu dotarła w swym rozwoju do momentu krytycznego, kiedy musiano zwrócić się do zapomnianej nieco filozofii z postulatem zmiany definicji pojęć. Oczekiwanym skutkiem kolejnych naukowych odkryć jest więc dalsze zbliżenie fizyki i filozofii, mogą one bowiem zakwestionować jeszcze inne powszechne przeświadczenia.

Należy jednak zauważyć, że pomimo przełomowego charakteru niektórych teorii, nie miały one wpływu na powszechne myślenie. Dzieje się tak, ponieważ na przykład załamanie determinizmu procesów w fizyce dotyczy tylko procesów w skali mikro, a co za tym idzie, w skali, której na co dzień człowiek nie doświadcza. Procesy dostępne dla zmysłów przebiegają ciągle tak samo od początku istnienia człowieka. Powierzchowny odbiór osiągnięć fizyki współczesnej umacnia raczej w ludzkości przekonanie o sile rozumu i wielkości człowieka jako pana i odkrywcy świata. Dopiero zagłębienie się w interpretację fizyki przez filozofów może pomóc właściwiej określić ich rzeczywiste znaczenie, a co za tym idzie, dowartościować filozofię jako konieczny element warsztatu fizyka.

Jak dotąd fizyka nie zdołała stworzyć spójnego systemu, który całkowicie wyjaśniłby wszystkie procesy wszechświata. Nie oznacza to jednak, że on nie istnieje, gdyż odebrałoby to wszelką nadzieję poświęcającym całe swoje życie badaniom naukowcom. Także „filozofowie mają prawo snuć domysły, lecz tylko Bóg wie, co się zdarzyło na Samym Początku, i - jak dotąd - skutecznie strzeże swej tajemnicy"’3.

\section{RELATIONS BETWEEN PHILOSOPHY AND MODERN SCIENCE ON THE EXAMPLE OF THE WRITINGS OF WERNER HEISENBERG}

\section{SUMMARY}

The article aims at presenting the relationship between science and philosophy based on the works of Werner Heisenberg. It deals with the influence of the scientific breakthrough on the understanding of physical concepts such as matter, time and

\footnotetext{
${ }^{73}$ L. Lederman, D. Teresi, Boska cząstka, tłum. E. Józefowicz, Warszawa 2012, s. 13.
} 
causality. It also contains a discussion on the process of creating a new branch of science - quantum mechanics, and shows how the work and views of Heisenberg contributed to it. The relationship between physics and philosophy is presented here with particular emphasis on showing the results of research and philosophical reflections on the concepts of matter, the philosophy of the language of science, the theory of unification and the flagship work of Heisenberg: the principle of uncertainty.

Keywords: Werner Heisenberg; physics and philosophy; philosophy of science; time; causality; matter; Heisenberg uncertainty principle

Słowa kluczowe: Werner Heisenberg; fizyka a filozofia; filozofia nauki; czas; przyczynowość; materia; zasada nieoznaczoności Heisenberga

\section{BIBLIOGRAFIA}

Dirac P.A.M., Matematyczne podstawy teorii kwantów, thum. M. Heller, „Zagadnienia Filozoficzne w Nauce", XII/1997, s. 107-112.

Gawecki B.J., Zagadnienie przyczynowości w fizyce, Warszawa 1969.

Grygiel W.P., Przekroczyć nieoznaczoność: relacje nauka - religia w myśli Wernera Heisenberga, w: Czy nauka zastapi religię?, red. B. Brożek, J. Mączka, Kraków 2011, s. 85-104.

Heisenberg W., Część i całość, thum. K. Napiórkowski, Warszawa 1987.

Heisenberg W., Fizyka a filozofia, tłum. S. Amsterdamski, Warszawa 1962.

Heisenberg W., Ponad granicami, thum. K. Wolicki, Warszawa 1979.

Heller M., Elementy mechaniki kwantowej dla filozofów, Kraków 2014.

Heller M., Logos wszechświata, Kraków 2013.

Heller M., Lubański M., Ślaga S., Zagadnienia filozoficzne wspótczesnej nauki - wstęp do filozofii przyrody, Warszawa 1992.

Katz R., Wstęp do szczególnej teorii względności, tłum. A. Blinowska, Warszawa 1967.

Kłósak K., Metafizyczna i fizyczna zasada przyczynowości wobec relacyj niedokładności W. Heisenberga , „Roczniki Filozoficzne KUL” I/1948, s. 198-213.

Lederman L., Teresi D., Boska czastka, thum. E. Józefowicz, Warszawa 2012.

Łukasik A., Atomizm dawniej i dziś. O niewspótmierności ontologicznej klasycznego i kwantowomechanicznego pojęcia elementarnych sktadników materii, „Studia Philosophiae Christianae” 45 (2009) 1, s. 133-162.

Łukasik A., Filozofia nauki Wernera Heisenberga, w: Filozofia - nauka - religia. Ksiega jubileuszowa dedykowana Profesorowi Kazimierzowi Jodkowskiemu z okazji 40-lecia pracy naukowej, red. P. Bylica, K.J. Kilian, R. Piotrowski i D. Sagan, Zielona Góra 2015, s. 345-362.

Pabjan T., Czas, hasło internetowej Encyklopedii Filozofii Przyrody KUL, http://www.kul.pl/ files/57/encyklopedia/pabjan_czas.pdf [dostęp: 08.08.2018].

Przechowski A., ,Równoczesność” a „,teraźniejszość” - fizyka i metafizyka czasu, „Roczniki Filozoficzne KUL", t. LXII, 4/2014, s. 181-204.

Sokołowski L., W poszukiwaniu teorii ostatecznej, w: Przestrzenie księdza Cogito. Księdzu Michatowi Hellerowi w sześćdziesiąta rocznicę urodzin, red. S. Wszołek, Tarnów 1996, s. 88-113.

Stachewicz K., Kilka uwag o racjonalności. Wprowadzenie, „Filozofia Chrześcijańska” 6 (2009), s. 7-16.

Tatarkiewicz W., Historia filozofii, t. 1, 3, Warszawa 2005.

Tempczyk M., Czas we wspótczesnej fizyce, „Ethos” nr 3(99) 2012, s. 231-244. 
van Melsen A., Filozofia przyrody, thum. S. Zalewski, Warszawa 1963.

von Weizsäcker C.F., Filozofia grecka i fizyka wspótczesna, „Zagadnienia Filozoficzne w Nauce” II / 1979/80, s. 1-17.

von Weizsäcker C.F., Wernerowi Heisenbergowi in memoriam, w: W. Heisenberg, Część i całość, thum. K. Napiórkowski, Warszawa 1987, s. 5-10.

Wróblewski A.K., Stowo wstęne, w: W. Heisenberg, Ponad granicami, thum. K. Wolicki, Warszawa 1979, s. 5-12.

Sebastian Sobkowiak MSF - magister, misjonarz Świętej Rodziny, prezbiter, absolwent Wyższego Seminarium Duchownego Zgromadzenia Misjonarzy Świętej Rodziny w Kazimierzu Biskupim, na Wydziale Teologicznym UAM. Interesuje się filozofią oraz współczesną nauką i technologią. Pochodzi z Poznania. 